\title{
The changes in the chemical and microbiological characteristics of lamtoro (Leucaena leucocephala) tempe from Pacitan with usar inoculum during continued fermentation
}

\author{
${ }^{1,2}$ Sari, A.M., ${ }^{1}$ Artini, D.A., ${ }^{1,2, *}$ Ishartani, D., ${ }^{1,2}$ Nursiwi, A. and ${ }^{1,2}$ Zaman, M.Z. \\ ${ }^{1}$ Department of Food Science and Technology, Faculty of Agriculture, Sebelas Maret University Jl.Ir.Sutami \\ 36 A Surakarta, Central Java, Indonesia 57126 \\ ${ }^{2}$ Halal Research Center, Sebelas Maret University, Jl.Ir.Sutami 36A Surakarta, Central Java, Indonesia \\ 57126
}

\author{
Article history: \\ Received: 7 December 2020 \\ Received in revised form: 18 \\ February 2021 \\ Accepted: 10 June 2021 \\ Available Online: 20 June \\ 2021
}

\section{Keywords:}

Pacitan lamtoro tempe, Continued fermentation, Fermentation time,

Amino acid

DOI:

https://doi.org/10.26656/fr.2017.5(S2).014

\begin{abstract}
In addition to soybean, Leucaena leucocephala is one of the tempe raw materials usually used in Indonesia. These tempe is only made by peoples in a few areas in the southern part of Java such as Wonogiri, Gunungkidul and Pacitan. For some purposes, such as cooking ingredients, tempe is deliberately fermented longer than usual to obtain a savory taste. In a previous study, we had studied leucaena tempe or people known as lamtoro tempe that process in Wonogiri and reported that there had been a change in characteristic during fermentation until over-fermented tempe. Therefore, in this research, we analyzed the change in the chemical and microbiological characteristic of lamtoro tempe from Pacitan during continued fermentation. This research showed that during the fermentation process, mold, yeast, and lactic acid bacteria (LAB) persisted for up to $126 \mathrm{hrs}$ of fermentation time. The growth of yeast and mold tend to decrease while LAB continued to increase until it reached $11 \log \mathrm{CFU} / \mathrm{mL}$. In addition, the moisture content, ash content, soluble protein levels, $\mathrm{pH}$ and titrated acid increased during continued fermentation time. Glutamic acid and aspartic acid were the highest amino acids by weight percentage. Both amino acids have an important role in the sensory characteristics of lamtoro tempe.
\end{abstract}

\section{Introduction}

Tempe is a traditional fermented food from Indonesia. Commonly tempe is made from dehulled cooked soybeans inoculated with certain mold spores or traditional starter culture called laru or usar. Other beans have been used to produce tempe in several regions, especially in Java. Koro benguk is the second choice of beans for tempe. Winged beans, mung beans, jack beans, and cowpeas are also used for tempe (Djaafar et al., 2019). This kind of tempe is popular in Central Java. Tempe may be made from lamtoro seeds in the southern part of Java. Lamtoro tempe producers exist in the Gunungkidul, Wonogiri, and Pacitan regions in Indonesia. Those tempe producers use a traditional starter (usar) and different preparation methods to produce tempe. Pacitan tempe producers use the usar from senggani leaves (Melastoma candidum), and Wonogiri tempe producers use the usar from teak leaves (Tectona gandis). Tempe inoculum can be obtained from the leaves used to wrap tempe that has been covered with tempe fungal mycelia. The fungal mycelia were then taken and dried under the sun (Wipradnyadewi et al., 2005).

Instead of the difference in the starter, there is some difference in tempe processing including the step of pretreatment process and packaging after inoculation. The pretreatment process of lamtoro tempe in Pacitan is different from the tempe produced in Wonogiri. In Pacitan. In Pacitan, the boiled seed was washed gently while peeling the hull without removing it. Meanwhile, tempe producers in Wonogiri peel the hull and remove it during washing the seed. So that producers in Pacitan use all parts of the seed unlike in Wonogiri which only uses the cotyledon part of the seeds. Furthermore, the packaging process also varies in each region. The lamtoro tempe in Pacitan is wrapped using two pieces of banana stalks joined together, then covered with senggani leaves. Meanwhile, tempe in Wonogiri is wrapped using teak leaves. There very few discussions on the making of traditional lamtoro tempe using usar from Pacitan. Research on lamtoro tempe was reported by Nursiwi (2018). Komari (1999) used commercial 
inoculum (Raprima), and Nursiwi (2019) used the traditional inoculum and processing method from Wonogiri.

Tanuwidjaja et al. (1991) mentioned that variations in ingredients, mixed materials, and inoculum utilizations, as well as the process of making tempe, greatly affect the quality of tempe. The characteristics of the tempe were influenced by more than the usar. The fermentation time caused changes in microbiological, chemical, and sensory characteristics in lamtoro tempe. Tempe would be over-fermented if stored for a certain time. The change from fresh to over-fermented tempe happened due to the microbiological change. The numbers of molds, yeasts, and lactic acid bacteria changed during tempe fermentation (Nurdini et al., 2015; Nursiwi, 2019).

Javanese people often used over-fermented tempe (or also called as "tempe bosok") as a cuisine or flavor enhancer. Over-fermented tempe is still widely consumed today. However, many people are reluctant to consume over-fermented tempe, so it is necessary to study the nutritional content of the over-fermented tempe. The results of previous studies explained that there were changes in various components during the tempe fermentation process. Research on Pacitan lamtoro tempe (Leucaena leucocephala) is required to examine the changes in the chemical and microbiological characteristics and the change in amino acid makeup of the Pacitan lamtoro tempe (Leucaena leucocephala) made with the usar inoculum. These changes need to be observed during advanced fermentation to determine the characteristic changes of the lamtoro tempe that had been allowed to ferment over time $(0,42,54,66,78,90$, $102,114$ and $126 \mathrm{hrs})$.

\section{Materials and methods}

\subsection{Materials}

Ripe lamtoro seeds (Leucaena leucocephala) and traditional usar inoculum were obtained from a lamtoro tempe producer in Pacitan District, East Java Province, Indonesia. Chemicals used were Lowry A solution, Lowry B solution, $\mathrm{CuSO} 4, \mathrm{NaK}$ tartaric, tartaric acid $0.1 \%$, chloramphenicol, $\mathrm{CaCO}_{3}, \mathrm{HCl}$, and distilled water. All chemicals were pro analysis grade. Media for mold enumeration was potato dextrose agar (PDA), for yeast enumeration was malt extract agar (MEA), and for lactic acid bacteria enumeration was de Man Rogosa Sharpe Agar (MRSA). All media were supplied by Merck, Darmstadt, Germany.

\subsection{Lamtoro tempe processing}

A total of $200 \mathrm{~g}$ of riped lamtoro seed were boiled for $3 \mathrm{hrs}$ with the addition of $0.29 \%(\mathrm{w} / \mathrm{w})$ of wooden ash obtained from burning residue. Afterwards, the boiled seeds were washed gently while peeled the hull then soaked for $48 \mathrm{hrs}$. Every $24 \mathrm{hrs}$ the soaked seeds were washed while changed the water. The process was followed by steaming the seeds for $1 \mathrm{hr}$ and letting the mixture cool to room temperature. Usar inoculum (55\%) was added to the lamtoro seeds, and the mixture was wrapped and incubated at $28 \pm 1{ }^{\circ} \mathrm{C}$ for $42 \mathrm{hrs}$ to produce fresh lamtoro tempe. Fermentation continued for 54, 66, $78,90,102,114$, and $126 \mathrm{hrs}$.

\subsection{Chemistry analysis}

Water and ash content analysis was performed using the AOAC (2005) method. Soluble protein was measured using Lowry et al. (1951). The $\mathrm{pH}$ was measured using a $\mathrm{pH}$ meter (Institute of Medicine, 2003). Acid was titrated using the percentage of lactic acid (Misgiyarta and Widowati, 2002). The amino acid was assessed by UPLC Waters $\mathrm{H}$ Class with a photodiode array detector (PDA) (Rohman and Gandjar, 2007; Waters, 2012).

\subsection{Microbial analysis}

The samples were taken immediately after lamtoro seed has been inoculated with laru $(0 \mathrm{hr})$ and every 12 hrs during continued fermentation begin from $42^{\text {nd }}$ hrs fermentation until $138^{\text {th }} \mathrm{hrs}$. Samples were collected from 3 times lamtoro tempe production. Approximately $1 \mathrm{~g}$ of each sample was crushed and homogenized in $9 \mathrm{~mL}$ of $0.85 \% \mathrm{NaCl}$ solution then each sample was serially diluted using sterile $0.85 \% \mathrm{NaCl}$ solution.

For lactic acid bacteria (LAB) enumeration, $1 \mathrm{~mL}$ of suspension from $10^{-5}-10^{-7}$ dilution was pour-plated with de Man Ragosa Sharpe Agar (Merck) supplemented with $1 \% \mathrm{CaCO}_{3}$ and $0.02 \mathrm{ppm}$ sodium azide then incubated $37^{\circ} \mathrm{C}$ for $48 \mathrm{hrs}$ (Nudyanto dan Zubaidah, 2015). While for yeast enumeration, $0.1 \mathrm{~mL}$ suspension from $10^{-2}-10^{-4}$ dilution was spread-plated on Malt Extract Agar (Merck) supplemented with $200 \mathrm{ppm}$ chloramphenicol and $0.5 \%$ calcium propionate then incubated $28^{\circ} \mathrm{C}$ for $48 \mathrm{hrs}$ (Ebabhi et al., 2013). Whereas mold enumeration was conducted by spread plating $0.1 \mathrm{~mL}$ suspension from $10^{-1}-10^{-3}$ dilution on Peptone Dextrose Agar (Merck) supplemented with $200 \mathrm{ppm}$ chloramphenicol and $0.1 \%$ tartaric acid then incubated $30^{\circ} \mathrm{C}$ for $48 \mathrm{hrs}$ (Da Silva et al., 2013). All plating for microbial analysis was done in two replicates and the total number of $\mathrm{LAB}$, yeast and mold colonies were expressed as the number of colonies per $\mathrm{mL}(\mathrm{CFU} / \mathrm{mL})$ sample. 


\subsection{Statistical analysis}

SPSS Version 25 software was used as the tool for statistical analysis. Data obtained were analyzed using one-way ANOVA with a significance level of 5\%. A further analysis was carried out using Duncan's multiple range test if there was a significant difference.

\section{Results and discussion}

\subsection{Microbial change}

Figure 1 shows that mold, yeast, and lactic acid bacteria (LAB) increased during the fermentation of fresh lamtoro tempe. The mold increased to $5.86 \mathrm{log}$ $\mathrm{CFU} / \mathrm{mL}$, and the appearance of hyphae was perfect and very compact. In this period, mold that entered the $\log$ phase was able to adapt well to its growth media (Purwoko, 2007). The mold was relatively constant between 54 and $78 \mathrm{hrs}$ of fermentation, began to decline at $90 \mathrm{hrs}$ and was still visible at $126 \mathrm{hrs}$ fermentation time. Mold in this research was more resistant than the mold in the lamtoro tempe inoculated using commercial inoculum. Nursiwi (2019) stated that the growth of mold was undetected at $108 \mathrm{hrs}$ fermentation of the lamtoro tempe from Wonogiri. This decrease was related to the $\mathrm{pH}$ data shown in Figure 1. The $\mathrm{pH}$ range was still in the optimum condition for the mold to grow (around $\mathrm{pH} 5.00$ -6.00). According to Pelczar and Chan (2008), the optimum $\mathrm{pH}$ for the mold's growth was 3.8-5.6.

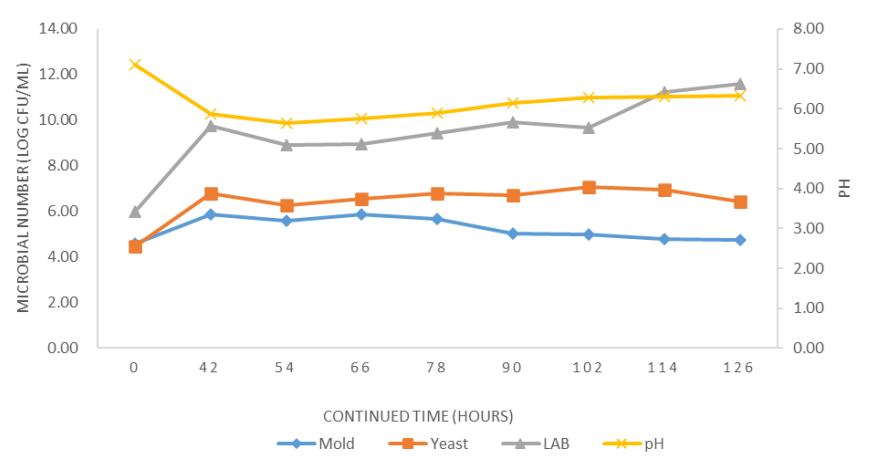

Figure 1. Lactic Acid Bacteria (LAB), mold, yeast, and $\mathrm{pH}$ in lamtoro tempe from Pacitan during continued fermentation

The yeast growth at $42 \mathrm{hrs}$ was quite high (6.81 log $\mathrm{CFU} / \mathrm{mL}$ ) and higher than the mold, which was only 5.86 $\log \mathrm{CFU} / \mathrm{mL}$ at the same fermentation time. The high yeast growth may be caused by the use of the traditional inoculum usar, which already contained yeast. The same results were found in the research conducted by Efriwati et al. (2013), which stated that the yeast growth in soybean tempe fermentation increased significantly from $3 \log \mathrm{CFU} / \mathrm{mL}$ to $6.85 \log \mathrm{CFU} / \mathrm{mL}$. The yeast was more abundant than the mold. At $126 \mathrm{hrs}$ fermentation, the yeast still appeared in lamtoro tempe from Pacitan, while at $96 \mathrm{~h}$, the yeast disappeared in tempe from Wonogiri (Nursiwi, 2019). This phenomenon was caused by the $\mathrm{pH}$ level of the lamtoro tempe in this research, which is optimum for yeast growth.

In the ready-to-incubate seed mixture, the $\mathrm{LAB}$ was detected at $5.97 \log \mathrm{CFU} / \mathrm{mL}$. After being fermented for $42 \mathrm{hrs}$, the amount of LAB increased significantly to $9.77 \log \mathrm{CFU} / \mathrm{mL}$ and kept rising until $126 \mathrm{hrs}$ fermentation, when it was found to be $11.59 \log \mathrm{CFU} /$ $\mathrm{mL}$. LAB growth during continued fermentation of lamtoro tempe was also reported by Nursiwi (2019). In addition, Nurdini (2015) mentioned that such a significant increase was presumed to be caused by the LAB's ability to use nutrients from fungi and yeast metabolites. The high LAB growth could be attributed to the total titrated acid levels, which can be seen in Figure 1. Meanwhile, the titrated acid level continued to increase during continued fermentation. Moreno et al. (2002) mentioned that the increase in the concentration of lactic acid in soybean tempe was caused by the growth of LAB that continued to increase to a density of $9 \log$ $\mathrm{CFU} / \mathrm{mL}$.

\section{$3.2 \mathrm{pH}$ and titrated acid}

The acidity level $(\mathrm{pH})$ is an important factor that affected tempe fermentation. The fermentation process is influenced by the $\mathrm{pH}$ value, and there is also a correlation between fungal growth and an increase in $\mathrm{pH}$ value (Rizal et al., 2020). It can be seen in Figure 1 that the $\mathrm{pH}$ value of lamtoro tempe tends to increase during continued fermentation, even though the increase was relatively small. Mold, LAB, and other bacteria are proteolytic, and both hydrolyze protein into amino acids and can form ammonia $\left(\mathrm{NH}_{3}\right)$. The higher the ammonia, the higher the $\mathrm{pH}$ level (Muzdalifah et al., 2016). A similar result was reported by Tahir et al. (2018), which found the $\mathrm{pH}$ of soybean tempe after $26 \mathrm{hrs}$ fermentation increased from 4.5 to 6.0. Meanwhile, during the $48 \mathrm{hrs}$ of fermentation, the $\mathrm{pH}$ of the lamtoro tempe continued to increase to 7.5. Andriati et al. (2018) found that the $\mathrm{pH}$ of jack bean tempe had the same level as the lamtoro tempe ( $\mathrm{pH}$ 6.18) at the beginning of the fermentation and increased at $60 \mathrm{~h}$ fermentation to 7.76.

Table 1 shows that the longer the fermentation time, the higher the value of the titrated acid. This value was closely related to the total number of lactic acid bacteria, which continued to increase. The highest titrated acid value of lamtoro tempe was found at the $54 \mathrm{hrs}$ fermentation time (Table 1), similar to the trend of soy tempe mentioned by Steven (2016). LAB growth may have entered the logarithmic phase when glucose breakdown occurred and resulted in an increase of titrated acid.

\subsection{Chemical change}


Table 1. Chemical change of lamtoro tempe in Pacitan during continued fermentation

\begin{tabular}{cccccc}
\hline Sample & $\begin{array}{c}\text { Fermentation } \\
\text { Time (Hrs) }\end{array}$ & $\begin{array}{c}\text { Moisture Content } \\
(\% \mathrm{wb})^{*}\end{array}$ & $\begin{array}{c}\text { Ash Content } \\
(\% \mathrm{db})^{*}\end{array}$ & $\begin{array}{c}\text { Soluble Protein } \\
\text { levels (\%db) }\end{array}$ & $\begin{array}{c}\text { Titratable } \\
\text { Acidity }(\%)^{*}\end{array}$ \\
\hline Ready to Incubate Seeds & 0 & $62.33 \pm 2.76^{\mathrm{a}}$ & $2.25 \pm 0.13^{\mathrm{a}}$ & $0.04 \pm 0.01^{\mathrm{a}}$ & $0.10 \pm 0.00^{\mathrm{a}}$ \\
& 42 & $64.48 \pm 0.96^{\mathrm{ab}}$ & $2.44 \pm 0.18^{\mathrm{a}}$ & $0.19 \pm 0.01^{\mathrm{b}}$ & $0.18 \pm 0.02^{\mathrm{b}}$ \\
& 54 & $66.01 \pm 1.63^{\mathrm{b}}$ & $2.42 \pm 0.57^{\mathrm{a}}$ & $0.41 \pm 0.40^{\mathrm{c}}$ & $0.57 \pm 0.05^{\mathrm{e}}$ \\
& 66 & $66.39 \pm 1.92^{\mathrm{b}}$ & $2.48 \pm 0.82^{\mathrm{ab}}$ & $0.51 \pm 0.02^{\mathrm{d}}$ & $0.37 \pm 0.06^{\mathrm{c}}$ \\
& 78 & $66.70 \pm 2.20^{\mathrm{b}}$ & $2.68 \pm 0.72^{\mathrm{ab}}$ & $0.58 \pm 0.02^{\mathrm{e}}$ & $0.42 \pm 0.07^{\mathrm{dc}}$ \\
& 90 & $70.25 \pm 2.98^{\mathrm{c}}$ & $2.76 \pm 0.41^{\mathrm{ab}}$ & $0.61 \pm 0.04^{\mathrm{e}}$ & $0.51 \pm 0.07^{\mathrm{de}}$ \\
& 102 & $69.96 \pm 0.65^{\mathrm{c}}$ & $2.89 \pm 0.41^{\mathrm{ab}}$ & $0.66 \pm 0.03^{\mathrm{f}}$ & $0.71 \pm 0.14^{\mathrm{fg}}$ \\
& 114 & $70.00 \pm 2.53^{\mathrm{c}}$ & $3.12 \pm 0.36^{\mathrm{b}}$ & $0.69 \pm 0.05^{\mathrm{f}}$ & $0.62 \pm 0.11^{\mathrm{ef}}$ \\
& 126 & $71.72 \pm 0.82^{\mathrm{c}}$ & $3.78 \pm 0.52^{\mathrm{c}}$ & $0.69 \pm 0.05^{\mathrm{f}}$ & $0.81 \pm 0.02^{\mathrm{g}}$ \\
\hline
\end{tabular}

Values are expressed as mean \pm SD. Values with different superscripts within the column are significantly different $(\alpha<0.05)$.

Fermentation time was one of the factors causing the microbiological and chemical changes in lamtoro tempe. As with soy tempe, fresh lamtoro tempe also has a short shelf life and would immediately over-ferment during storage. The fermentation process, including continued fermentation during storage, caused changes in chemical components from complex forms to simpler compound forms.

Water is one of the results of the metabolic process that greatly affected other components, including the growth of microorganisms that have an essential role in tempe fermentation. The water content of the lamtoro seeds just before incubation and during fermentation could be seen in Table 1 . The lamtoro seeds ready for incubation contained $62.33 \%$ moisture, which increased significantly to $71.72 \%$ at the end of fermentation. Fresh lamtoro tempe fermented for $42 \mathrm{hrs}$ contained $64.48 \%$ water, similar to fresh soybean tempe that has been fermented for $24 \mathrm{hrs}(62.38 \%)$ as reported by (Tahir et al., 2018). During tempe fermentation, microbes produced water, carbon dioxide and ATP during their metabolic process. The Rhizopus mold breaks the matrix between the bacterial cells on the third day of storage when the tempe became soft, and then the cells in the tempe were destroyed by the water from the breakdown of carbohydrates. This physical change is one of the factors that makes the over-fermented tempe soft and juicy.

The ash content of lamtoro continued to increase along with the increasing fermentation time (Table 1). The increase in ash content was thought to be caused by the vitamins formed by bacteria that continued to grow during the tempe fermentation, especially vitamin B12 (Omosebi and Otunola, 2013). Astuti et al. (2000) mentioned that the amount of vitamin B complex increased during the fermentation process, except for thiamine. Vitamin B12 contained nitrogen and a cobalt (Co) atom. Cobalt is similar to the iron-bound in hemoglobin or the magnesium bound in chlorophyll.
Table 1 shows that soluble protein levels continued to increase along with the increasing fermentation time from $0.04 \%$ in seeds ready for incubation to $0.69 \%$ in lamtoro tempe incubated for $126 \mathrm{hrs}$. Such an increase was attributed to the activity of the protease enzyme produced by the mold during its growth. This enzyme breaks down complex proteins into simpler protein compounds by breaking the peptide bonds. The chainbreaking caused the protein to dissolve easily, so that soluble protein levels increased (Arianingrum et al., 2007)

\subsection{Amino acids composition}

Lamtoro seeds contained several essential amino acids, such as arginine, cysteine, alanine glutamic acid, isoleucine, leucine, and lysine (Benjakul et al., 2014). In this research, other amino acids, such as serine, valine, glycine, threonine, aspartic acid, tyrosine, proline, and histidine, were found in the lamtoro tempe produced in Pacitan District (Table 2). Amino acid levels of lamtoro tempe changed during the fermentation process and continued to change during the fermentation of fresh tempe to over-fermented lamtoro tempe.

During further fermentation, there was a change in the content of 15 amino acids. The amount of L-valine, $\mathrm{L}$ -alanine, glycine, L-lysine, and L-threonine was fluctuated and tend to increase, otherwise, the amount of L-serine, L-glutamic acid, L-phenylalanine, L-isoleucine, L-arginine, L-aspartic acid, L-leucine, L-tyrosine, Lproline, and L-histidine tend to decrease. During continued fermentation, L-glutamic acid had the highest reduction $(29 \%)$. However, at the end of continued fermentation (126 hrs), its content was the highest among other amino acids, followed by L-aspartic acid. A similar result was reported by Handoyo and Morita (2007), in which the amount of glycine increased gradually during the over-fermentation of soybean tempe. Meanwhile, the levels of non-essential amino acids, especially alanine, aspartic acid, cysteine, proline, 
Table 2. Amino acid Composition ( $\% \mathrm{dw})$ of lamtoro tempe in Pacitan during continued fermentation

\begin{tabular}{|c|c|c|c|c|c|c|c|c|c|}
\hline \multirow{2}{*}{ Amino acid } & $0 \mathrm{hrs}$ & $42 \mathrm{hrs}$ & \multirow{2}{*}{$54 \mathrm{hrs}$} & \multirow{2}{*}{$66 \mathrm{hrs}$} & \multirow{2}{*}{$78 \mathrm{hrs}$} & \multirow{2}{*}{$90 \mathrm{hrs}$} & \multirow{2}{*}{$102 \mathrm{hrs}$} & \multirow{2}{*}{$114 \mathrm{hrs}$} & \multirow{2}{*}{$126 \mathrm{hrs}$} \\
\hline & (Ready to Incubate) & $\begin{array}{l}\text { (Fresh Tempe) } \\
\end{array}$ & & & & & & & \\
\hline L-Serine & 1.33 & 1.13 & 1.07 & 1.15 & 1.05 & 0.98 & 1.00 & 0.92 & 1.14 \\
\hline L- Glutamic acid & 2.81 & 2.29 & 2.46 & 2.35 & 2.21 & 2.03 & 2.43 & 2.11 & 1.98 \\
\hline L-Phenylalanine & 1.73 & 1.57 & 1.21 & 1.44 & 1.08 & 1.25 & 1.26 & 1.19 & 1.48 \\
\hline L-Isoleucine & 0.80 & 0.84 & 0.79 & 0.88 & 0.72 & 0.74 & 0.87 & 0.67 & 0.71 \\
\hline L-Valine & 0.99 & 1.16 & 1.05 & 1.12 & 0.99 & 1.11 & 1.18 & 1.03 & 1.12 \\
\hline L-Alanine & 1.04 & 1.28 & 1.44 & 1.38 & 1.42 & 1.57 & 1.68 & 1.54 & 1.64 \\
\hline L-Arginine & 2.61 & 1.53 & 1.53 & 1.40 & 1.26 & 0.87 & 1.00 & 0.94 & 1.22 \\
\hline Glycine & 1.33 & 1.31 & 1.36 & 1.34 & 1.35 & 1.33 & 1.33 & 1.23 & 1.61 \\
\hline L-Lysine & 0.88 & 0.89 & 1.05 & 0.97 & 1.05 & 0.78 & 1.03 & 1.01 & 0.97 \\
\hline L-Aspartic acid & 1.96 & 1.71 & 1.97 & 1.93 & 1.95 & 1.94 & 2.02 & 1.84 & 1.93 \\
\hline L-Leucine & 1.51 & 1.47 & 1.37 & 1.50 & 1.18 & 1.22 & 1.43 & 1.12 & 1.20 \\
\hline L-Tyrosine & 1.05 & 1.05 & 0.89 & 0.98 & 0.78 & 0.86 & 0.90 & 0.92 & 1.04 \\
\hline L-Proline & 0.88 & 0.79 & 0.75 & 0.78 & 0.68 & 0.69 & 0.76 & 0.64 & 0.69 \\
\hline L-Threonine & 0.90 & 0.93 & 0.91 & 1.01 & 0.84 & 0.87 & 0.94 & 0.84 & 1.02 \\
\hline L-Histidine & 0.91 & 0.82 & 0.67 & 0.76 & 0.58 & 0.51 & 0.76 & 0.54 & 0.64 \\
\hline
\end{tabular}

and serine, increased during fermentation. The levels of other amino acids, such as glutamic acid and asparagine fluctuated during fermentation but showed the highest amounts at $72 \mathrm{hrs}$ of fermentation. The decrease in the amount of glutamic acid after $102^{\text {nd }}$ hrs fermentation can be affected by the decrease in the number of mold colonies. In addition, glutamic acid and other amino acids can be utilized by lactic acid bacteria, which show an increase in the number of colonies until the end of fermentation (Figure 1). Kawai et al. (2007) and Tseng et al. (2005) explained that glutamic acid was important for the umami (savory) taste. The use of over-fermented lamtoro tempe from Pacitan as a flavoring agent was supported by this amino acid profile.

\section{Conclusion}

In this research, the continued fermentation of the lamtoro tempe from Pacitan affected its microbiological and chemical characteristics. Continued fermentation up to $126 \mathrm{hrs}$ triggered the increase of $\mathrm{pH}$, mold, yeast, and LAB. Changes in chemical characteristics such as water, ash, and dissolved protein content also increased every $12 \mathrm{hrs}$ during continued fermentation. Of the 15 types of amino acids in the over fermented lamtoro tempe, the levels of L-valine, L-alanine, glycine, L-lysine, Lthreonine acids increased. Meanwhile, the levels of Lserin, L-glutamic acid, L-phenylalanine, L-isoleucine, Larginine, L-aspartic acid, L-leucine, L-tyrosine, Lproline, and L-histidine decreased. The amino acids Lglutamic acid and L-aspartic acids were the highest by weight percentage in both fresh and over-fermented lamtoro tempe.

\section{Conflict of interest}

The authors declare no conflict of interest.

\section{Acknowledgments}

The research was financially supported by Universitas Sebelas Maret through Pusat Keunggulan Research Scheme in 2017 (Grant number 623/UN27.21/ $\mathrm{PP} / 2017)$.

\section{References}

Andriati, N., Anggrahini, S., Setyaningsih, W., Sofiana, Pusparasi, D.A. and Mossberg, F. (2018). Physicochemical characterization of jack bean (Canavalia ensiformis) tempe. Food Research, 2(5), 481-485. https://doi.org/10.26656/fr.2017.2(5).300

AOAC. (2005). Official Methods of Analysis of the Association of Official Analytical Chemists. Washington D.C.: AOAC International.

Arianingrum, R., Sulistyowati, E. and Salirawati, D. (2007). Pengaruh Lama Fermentasi Tempe Kedelai terhadap Aktivitas Tripsin. Jurnal Penelitian Saintek, 12(2), 172-192. [In Bahasa Indonesia].

Benjakul, A., Kittiphattanabawon, P., Shahidi, F. and Maqsood, S. (2014). Antioxidant Activity and Inhibitory Effects of Lead (Leucaena leucocephala) Seed Extracts against Lipid Oxidation in Model Systems. Journal of Food Science and Technology International, 19(4), 365-374. https:// doi.org/10.1177/1082013212455186

Da Silva, N., Taniwaki, M.H., Junqueria, V.C.A., Silviera, D. Maristela, D. and Gomes, R.A. (2013). Microbiological Examination Methods of Food and Water: A Laboratory Manual. London: CRC Press.

Djaafar, T.F., Marwati T. and Purwaningsih. (2019). Indonesia Local Beans and Its Benefit as Functional Food. Jurnal of Food Technology and Food Chemistry, 2(1), 105. 
Ebabhi, A.M., Adekunle, A.A., Okunowo and Akinninyl. (2013). Isolation and Characterization of Yeast Strains from Local Food Crops. Journal of Yeast and Fungal Research, 4(4), 38-39.

Efriwati, Suwanto, A., Rahayu, G. and Nuraida, L. (2013). Population Dynamics of Yeasts and Lactic Acid Bacteria (LAB) during Tempe Production. Hayati Journal of Biosciences, 20(2), 57-64. https:// doi.org/10.4308/hjb.20.2.57

Handoyo, T. and Morita, (2007). Structural and Functional Properties of Fermented Soybean (Tempe) by Using Rhizopus oligosporus. International Journal of Food Properties, 9(2), 347355. https://doi.org/10.1080/10942910500224746

Institute of Medicine. (2003). Food Chemicals Codex. $5^{\text {th }}$ ed. Washington, DC.: The National Academies Press.

Kawai, M., Uneyama, H. and Miyano, H. (2009). Tasteactive Components in Foods, with Concentration on Umami Compounds. Journal of Health Science, 55 (5), 667-673. https://doi.org/10.1248/jhs.55.667

Lowry, O.H., Rosenbourgh, N.J., Farr, A.L. and Randall, R.J. (1951). Protein Measurement with the Folin Phenol Reagent. Journal of Biological Chemistry, 193, 265-275. https://doi.org/10.1016/S0021-9258 (19)52451-6

Moreno, M.R.F., Leisner, J.J., Tee, L.K., Ley, C., Radu, S., Rusul, G., Vancanneyt, M. and de Vuyst. (2002). Microbial analysis of Malaysia tempe, and characterization of two bacteriocins produced by isolates of Enterococcus faecium. Journal of Applied Microbiology, 92(1), 147-157. https:// doi.org/10.1046/j.1365-2672.2002.01509.x

Muzdalifah, D., Athaillah, Z.A., Nugrahaini, W. and Devi, A.F. (2017). Colour and pH Changes of during Extended Fermentation. International Symposium on Applied Chemistry, 1803, 020036. https:// doi.org/10.1063/1.4973163

Nudyanto, A. and Zubaidah, E. (2015). Isolasi Bakteri Asam Laktat Penghasil Eksopolisakarida dari Kimchi. Jurnal Pangan dan Agroindustri, 3(2), 732748.

Nurdini, A.L., Nuraida, Suwanto and Suliantri. (2015). Microbial Growth Dynamics during Tempe Fermentation in Two Different Home Industries. International Food Reseacrh Journal, 22(4), 16681674.

Nursiwi, A., Dwikiputra, B.I., Ishartani, D. and Sari, A.M. (2019). Change on Microbial Growth during MLanding tempe (Leucaena leucocephala) over fermentation. IOP Publishing, 379, 1-6. https:// doi.org/10.1088/1755-1315/379/1/012001
Omosebi M.O and Otunola E.T. (2013). Preliminary Studies on Tempe Flour Produced from Three Different Rhizopus species. International Journal of Biotechnology and Food Science, 1(5), 90-96.

Pelczar, M.J. and Chan, M.C.S. (2008). Dasar-dasar Mikrobiologi Jilid I. Jakarta: UI-Press. [In Bahasa Indoneisa].

Purwoko, T. (2004). Kandungan Isoflavon Aglikon pada Tempe Hasil Fermentasi Rhizopus microsporus var. oligosporus, Pengaruh Perendaman. Jurnal Biosmart Journal, 6(2), 85-87.

Rizal, S., Murhadi, Kustyawati, M.E. and Hasanudin, U. (2020). Growth Optimization of Saccharomyces cerevisiae during fermentation to produce tempe with high $\beta$-glucan content. Biodiversitas, 21(6), 2667-2673. https://doi.org/10.13057/biodiv/d210639

Rohman, A. and Gandjar, I.G. (2007). Metode Kromatografi Untuk Analisis Makanan. Yogyakarta: Pustaka Pelajar. [In Bahasa Indonesia].

Steven. (2016). Seleksi Bakteri Asam Laktat Asal Tempe terhadap Aktvitas Enzim BetaGlukosidase. Bogor: Institute Pertanian Bogor, BSc. Thesis. [In Bahasa Indonesia].

Tahir, A., Anwar, M., Mubeen H. and Raza, S. (2018). Evaluation of Physicochemical and Nutritional Conten in Soybean Fermented Food Tempe by Rhizopus oligosporus. Journal of Advances in Biology and Biotechnology, 17(1), 1-9. https:// doi.org/10.9734/JABB/2018/26770

Tanuwidjaja, L., Hariyadi. H.R. and Mulyati, Y. (1991). Faktor-faktor yang Mempengaruhi Kualitas Tempe di Indoensia. Jurnal Kimia Terapan Indonesia, 1(1), 31-34. [In Bahasa Indonesia].

Tseng Y.H., Lee, Y.L., Li, R.C. and Mau, J.L. (2005). Non-volatile flavor components of Ganoderma tsugae. Food Chemistry, 90(3), 409-415. https:// doi.org/10.1016/j.foodchem.2004.03.054

Waters. (2012). Acquity UPLC H-Class and H-Class Bio Amino Acid Analysis System Guide. Retrieved on September 23, 2020 from Waters Website: https:// www.waters.com/webassets/cms/support/docs/ acq_uplc_h-class_aaa_sysgd_rev_b.pdf

Wipradnyadewi, P.A.S., Rahayu, E. and Raharjo. S. (2005). Isolasi dan Identifikasi Rhizopus oligosporus pada Beberapa Inokulum Tempe. Jurnal Agrotekno, 11(2), 3089. [In Bahasa Indonesia]. 